\title{
Molecular Diversity Analysis of Soybean Genotypes Using Molecular Markers
}

\author{
A.A. Bharose*, V.D. Kulkarni and D.N. Damse \\ V.D. College of Agricultural Biotechnology, Latur, M.K.V., Parbhani 431402 (M.S.), India \\ *Corresponding author
}

\begin{tabular}{|c|c|}
\hline & A B S T R A C T \\
\hline $\begin{array}{l}\text { Ke y w o r d s } \\
\text { DNA fingerprinting, } \\
\text { RAPD, Soybean. }\end{array}$ & \multirow{3}{*}{$\begin{array}{l}\text { Soybean is legume crop having high protein }(40 \%) \text { and oil }(20 \%) \text { content. It has highest } \\
\text { share in production among all oilseeds of the world. In present study } 10 \text { soybean genotypes } \\
\text { were characterized using } 14 \text { RAPD primers. Total } 103 \text { amplicons were obtained out of } \\
\text { which } 75 \text { were polymorphic and } 28 \text { were monomorphic. The percent polymorphism } \\
\text { obtained was } 72.81 \% \text {. Highest average similarity coefficient was exhibited by the } \\
\text { genotype MAUS-32 }(0.675) \text { and lowest similarity coefficient exhibited by MAUS- } 2 \\
\text { (0.584). The dendrogram of these genotypes grouped into two main clusters. These two } \\
\text { clusters again divided into } 6 \text { sub-clusters having distinct morphological and physiological } \\
\text { characteristics. }\end{array}$} \\
\hline Article Info & \\
\hline $\begin{array}{l}\text { Accepted: } \\
\text { 24 February } 2017 \\
\text { Available Online: } \\
\text { 10 March } 2017\end{array}$ & \\
\hline
\end{tabular}

\section{Introduction}

Soybean (Glycine Max L. Merril) is annual legume crop originated in China. It ranks first among all oilseeds crops of world having 50 percent share in total oilseed production (Anonymous, 2009). In India large number of soybean varieties has been released for cultivation. To test genetic resources for their productivity, quality parameters and stress tolerance, field trials are usually time consuming therefore, molecular markers are used to assess diversity in the gene pool to identify genes of interest and to develop a set of markers for screening progenies (Karp et al., 1997). Many types of molecular markers viz. RAPD, AFLP, RFLP, ISSR, SSRs are becoming increasingly important for cultivar identification and diversity analysis. In soybeans dense genetic maps were developed using RFLP and AFLP markers (Keim et al., 1997). Also PCR based intraspecific RAPD map is built, however number of polymorphism was relatively small due to narrow genetic base of cultivated soybean (Abdelnoor et al., 1995). There are several reports of using molecular markers for evaluation of genetic diversity, out of which RAPD markers have been shown to be a simple and effective means to evaluate variability; because they are technically simple, non radioactive, inexpensive and require small amount of DNA. In the view of above content, the present study has been carried out to analyse genetic diversity of selected accessions from Soybean Research Station, M.K.V., Parbhani (Maharashtra).

\section{Materials and Methods}

Ten Soybean genotypes exhibiting different phenotypic characters were used for this study (Anonymous, 2006) (Table 1). Seeds were germinated on germination papers kept at 
$37^{\circ} \mathrm{C}$. After 7 days 1.2 to $2 \mathrm{~g}$ shoot portion of seedlings was used for DNA extraction. Genomic DNA was extracted by using modified CTAB method of DNA isolation (Bhat et al., 1999; Saghai et al., 1984). The extraction buffer consisted of EDTA (20 $\mathrm{mM})$, Tris-HCL having $\mathrm{pH} 8.0(100 \mathrm{mM})$, $\mathrm{NaCl} \quad(1.4 \mathrm{M}), \quad \mathrm{CTAB} \quad(2 \%), \quad \beta-$ mercaptoethanol $(0.2 \%)$. Leaf tissues were grounded to fine powder in liquid nitrogen ($196^{\circ} \mathrm{C}$ ) with mortar and pestle. To the powdered tissue, $2 \mathrm{ml}$ of extraction buffer was added and mixed well by gentle inversion and incubated at $65^{\circ} \mathrm{C}$ for $30 \mathrm{~min}$ in a water bath. The mixture was then subjected to centrifugation at $10,000 \mathrm{rpm}$ at $4^{\circ} \mathrm{C}$ temperature for $10 \mathrm{~min}$. The supernatant was taken and then mixed with equal volume of freshly prepared Chloroform: Isoamyl alcohol and recentrifuged at $10,000 \mathrm{rpm}$ for $10 \mathrm{~min}$. at $4^{\circ} \mathrm{C}$ temperature then collected the supernatants into a fresh tube. To the collected supernatants, 0.7 volume of chilled isopropanol was added mixed well and DNA was allowed to precipitate at $20^{\circ} \mathrm{C}$ for overnight. The DNA was pelleted by centrifugation at $10,000 \mathrm{rpm}$ for $10 \mathrm{~min}$ at room temperature. Collected pellet was washed with 70 percent alcohol and dissolved in optimum quantity of TE buffer. DNase free RNase-A was added at a final concentration of $20 \mu \mathrm{g} / \mathrm{ml}$ and incubated at $37^{\circ} \mathrm{C}$ for 1 hour in hot water bath. To the incubated sample equal volume of phenol: chloroform (1:1) mixture was added and centrifuged at 10,000 rpm for 10 minutes. The aqueous phase was collected in fresh tube. To the aqueous phase 0.1 volume of sodium acetate and 2 volumes of ice cold absolute ethanol was added, mixed well and kept it at $-20^{\circ} \mathrm{C}$ for 1 hour. The DNA was then repelleted by centrifugation at $10,000 \mathrm{rpm}$ for $10 \mathrm{~min}$ at room temperature. The collected pellet was rewashed with 70 per cent alcohol air dried and dissolved in optimum quantity of TE buffer and stored at $20^{\circ} \mathrm{C}$.
Fifty random primers from OPA, OPG, OPM, OPF, OPG, OPR, OPJ, OPX, OPH series (Bio Serve Biotechnologies, India Pvt. Ltd. Hyderabad) were screened out of them fourteen primers (OPA-6, OPA-10, OPA-13, OPX-11, OPX-14, OPM-05, OPM-20, OPG09, OPG-12, OPF-10, OPF-12, OPR-04, OPH-20, OPJ-01) were selected for RAPD analysis. PCR was carried out in $25 \mu \mathrm{l}$ reaction volume containing 10X PCR buffer (with KCL) $2.5 \mu \mathrm{l}$, dNTPs $(10 \mathrm{mM}) 0.5 \mu \mathrm{l}$, $\mathrm{MgCl}_{2}(25 \mathrm{mM}) 1.5 \mu \mathrm{l}$, primer $(20 \mathrm{pm} / \mu \mathrm{l}) 1.5$ $\mu \mathrm{l}$, Taq DNA polymerase $(1.5 \mathrm{U} / \mu \mathrm{l}) 0.3 \mu \mathrm{l}$, template DNA (25 ng) $1.0 \mu \mathrm{l}$ and sterile double distilled water $17.7 \mu \mathrm{l}$. Amplification was programmed for 35 cycles with initial denaturation at $94^{\circ} \mathrm{C}$ for $4 \mathrm{~min}$., followed by cycling conditions of denaturation at $94^{\circ} \mathrm{C}$ for $1 \mathrm{~min}$, annealing at $35^{\circ} \mathrm{C}$ at $1 \mathrm{~min}$. and extension at $72{ }^{\circ} \mathrm{C}$ for $2 \mathrm{~min}$. After 35 cycles, there was a final extension step of $10 \mathrm{~min}$ at $72{ }^{\circ} \mathrm{C}$. The amplicons were analyzed on $1.5 \%$ agarose gels at $100 \mathrm{~V}$ for 4 hours and detected by staining with ethidium bromide. UV transilluminated gels were photographed with gel documentation system (Alphaimager TM 2200).

The amplified products were scored for presence (1), absence (0), missing and doubtful case was scored as 9. Band size was determined by comparison with $1 \mathrm{~kb}$ DNA ladder (MBT, Fermentas, U. K.) as standard.

The data was used for similarity based analysis using programme NTSYS-PC (Version 2.02) developed by (Rolf et al., 1993) Jaccard's similarity coefficients (F') was calculated using the programme SIMQUAL. Similarity coefficients were used to construct UPGMA (unweighted pair group method with average) to generate dendrogram. The polymorphic percentage of the obtained bands were calculated by using following formula 
Polymorphic $\%=$ (no. of polymorphic bands /Total bands) X 100

\section{Results and Discussion}

Total 103 amplicons were generated with an average of 7.4 amplicons per primer, out of them 28 were monomorphic and 75 polymorphic. The result showed average $72.81 \%$ polymorphism, highest i. e. $100 \%$ polymorphism was recorded in primer OPM20, OPH-20 and OPX-11. Average monomorphic band were 2 (Table 2) while, average polymorphic bands were 5.3 (Fig. 2).

Genetic relationship was determined on the basis of jaccard's similarity coefficient values, these values ranged from 0 to 1 (Table 3 and 4). Average genetic similarity coefficient was 0.634. Cluster analysis revealed by dendrogram (fig. 1) shown these accessions into two super clusters ' $A$ ' and ' $B$ ' at 59 per cent similarity. Super cluster ' $A$ ' accommodates 6 genotypes having early maturity character. Super cluster 'B' contains
4 genotypes which are high yielding and having pest resistance. Super clusters 'A' divided into 6 sub clusters in which sub cluster-I contains only one variety MAUS-1 having early maturity as distinct character and which is also suitable for intercropping. Sub cluster-II contains two varieties MAUS-32 and MAUS-61-2 having early maturity and Non - shattering characters common, these two varieties having $76 \%$ similarity. Sub cluster-III contains two varieties MAUS-47 and MAUS-61 having about $81 \%$ similarity, these genotypes are having round seeds and early maturity. Sub cluster-IV contains only one genotype MAUS-2 which is having white colour flowers and high oil content and unique marker associated with this trait is OPA-13. Sub cluster-V contains two genotypes MAUS-71 and MAUS-81with about $72 \%$ similarities, these varieties are having good germination and high yielding character. Sub cluster-VI contains two varieties MAUS-158 and MAUS-162 with about $77 \%$ similarity are high yielding and having pest resistance.

Table.1 List of Soybean genotypes with characters

\begin{tabular}{|c|c|c|c|c|c|}
\hline $\begin{array}{l}\text { Sr. } \\
\text { No. }\end{array}$ & Variety & $\begin{array}{l}\text { Days to } 50 \% \\
\text { flowering }\end{array}$ & $\begin{array}{l}\text { Days to } \\
\text { maturity }\end{array}$ & $\begin{array}{l}\text { Flower } \\
\text { colour }\end{array}$ & Characters \\
\hline 1 & MAUS-1 & 40 & 95 & Purple & Early, suitable for intercropping \\
\hline 2 & MAUS-2 & 39 & 90 & white & Early, high oil content \\
\hline 3 & MAUS-32 & 40 & 90 & purple & Early, Non- shattering, \\
\hline 4 & MAUS-47 & 38 & 85 & purple & $\begin{array}{l}\text { Very early, round seeds, good } \\
\text { germination }\end{array}$ \\
\hline 5 & MAUS-61 & 40 & 95 & purple & $\begin{array}{l}\text { Early, round seeds, good } \\
\text { germination }\end{array}$ \\
\hline 6 & MAUS-61-2 & 39 & 95 & Purple & Early, round seeds,Non-shattering \\
\hline 7 & MAUS-71 & 38 & 100 & Purple & Good germination, High yielding \\
\hline 8 & MAUS-81 & 40 & 105 & Purple & High yielding, good germination \\
\hline 9 & MAUS-158 & 40 & 100 & Purple & pest resistance \\
\hline 10 & MAUS-162 & 42 & 100 & Purple & pest resistance \\
\hline
\end{tabular}


Table.2 RAPD amplicons/bands produced by soybean genotypes

\begin{tabular}{|c|c|c|c|c|c|}
\hline $\begin{array}{l}\text { Sr. } \\
\text { No. }\end{array}$ & Primer & $\begin{array}{c}\text { Total no. } \\
\text { of } \\
\text { amplicons }\end{array}$ & $\begin{array}{c}\text { No. of } \\
\text { monomorphic } \\
\text { amplicons }\end{array}$ & $\begin{array}{c}\text { No. of } \\
\text { polymorphic } \\
\text { amplicons }\end{array}$ & $\begin{array}{c}\text { Percent } \\
\text { polymorphism }\end{array}$ \\
\hline 1 & OPA-06 & 10 & 2 & 8 & 80 \\
\hline 2 & OPA-10 & 6 & 3 & 3 & 50 \\
\hline 3 & OPX-14 & 8 & 4 & 4 & 50 \\
\hline 4 & OPR-04 & 5 & 2 & 3 & 60 \\
\hline 5 & OPA-13 & 7 & 2 & 5 & 71.42 \\
\hline 6 & OPG-12 & 9 & 1 & 8 & 88.88 \\
\hline 7 & OPM-05 & 7 & 2 & 5 & 71.42 \\
\hline 8 & OPM-20 & 9 & 0 & 9 & 100 \\
\hline 9 & OPH-20 & 3 & 0 & 3 & 100 \\
\hline 10 & OPF-10 & 9 & 3 & 6 & 66.66 \\
\hline 11 & OPX-11 & 10 & 0 & 10 & 100 \\
\hline 12 & OPG-09 & 9 & 5 & 4 & 44.44 \\
\hline 13 & OPF-12 & 6 & 3 & 3 & 50 \\
\hline 14 & OPJ-01 & 5 & 1 & 4 & 80 \\
\hline \multicolumn{2}{|c|}{ Total } & 103 & 28(Avg. $27.18 \%)$ & 75(Avg. $72.81 \%)$ & Avg. $72.34 \%$ \\
\hline
\end{tabular}

Table.3 Average similarity Index of 10 soybean genotypes

\begin{tabular}{|c|l|l|c|l|l|}
\hline Sr. No & Variety & $\begin{array}{l}\text { Average similarity } \\
\text { value }\end{array}$ & Sr. No & Variety & $\begin{array}{l}\text { Average similarity } \\
\text { value }\end{array}$ \\
\hline 1 & MAUS-1 & 0.640 & 6 & MAUS-61-2 & 0.654 \\
\hline 2 & MAUS-2 & 0.584 & 7 & MAUS-71 & 0.603 \\
\hline 3 & MAUS-32 & 0.675 & 8 & MAUS-81 & 0.640 \\
\hline 4 & MAUS-47 & 0.673 & 9 & MAUS-158 & 0.614 \\
\hline 5 & MAUS-61 & 0.66 & 10 & MAUS-162 & 0.603 \\
\hline
\end{tabular}




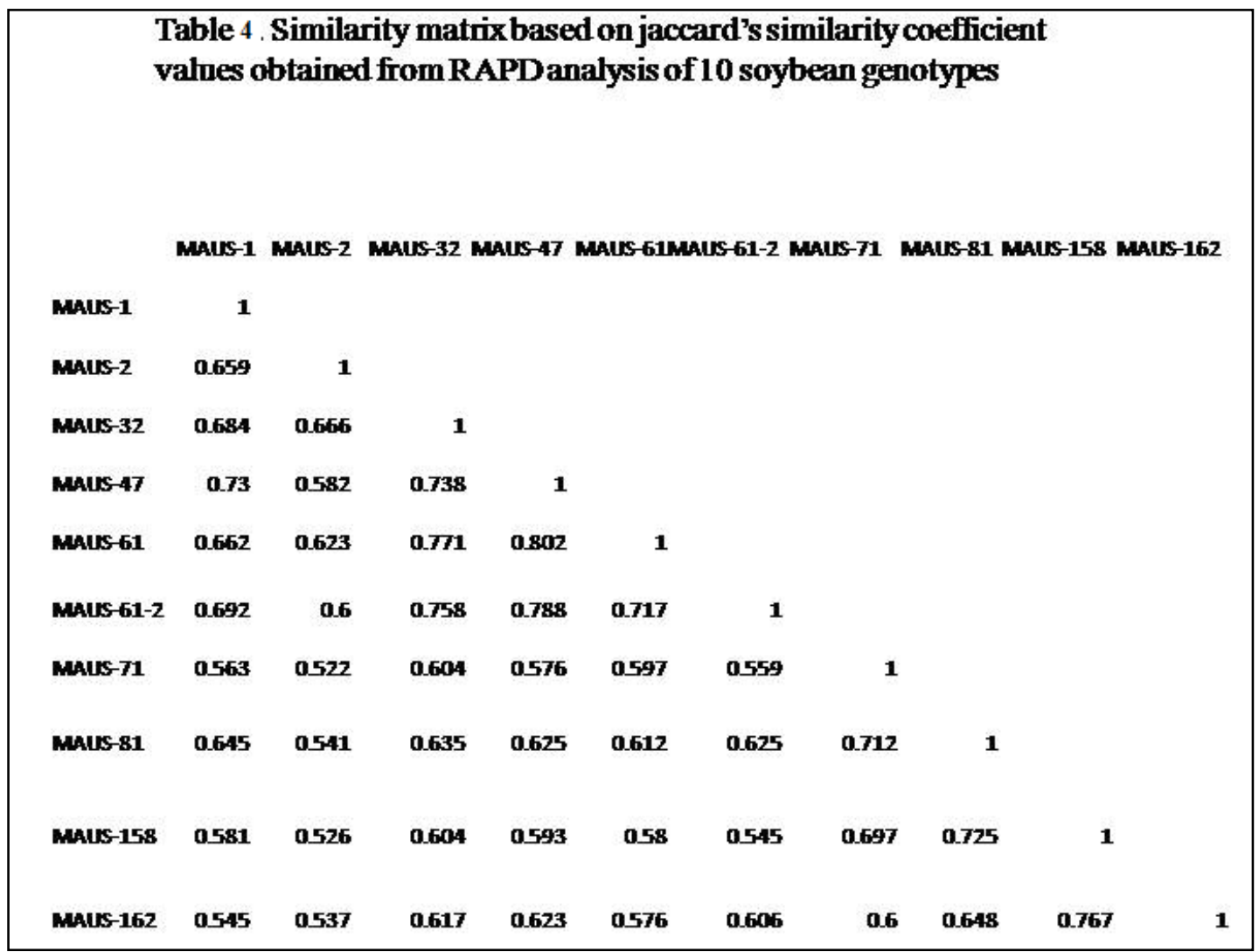

Figure.1 Dendrogram Generated by UPGMA analysis based on RAPD data showing relationship among soybean genotypes

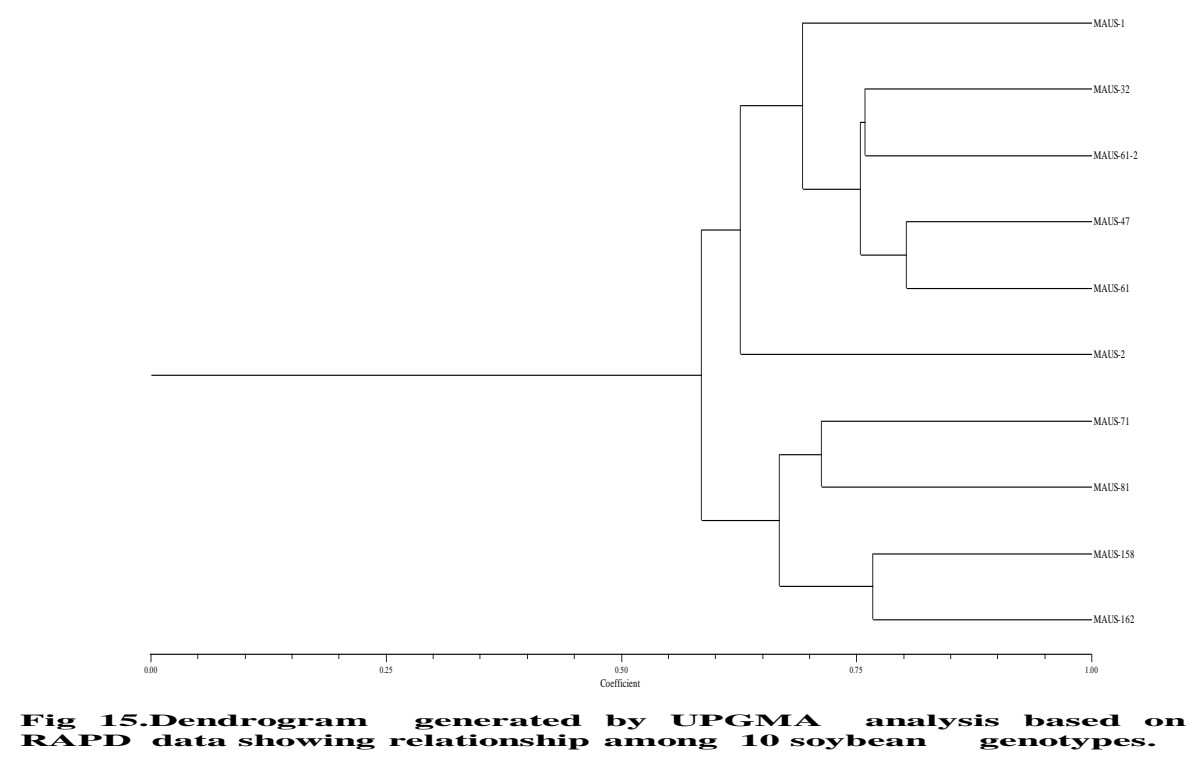


Figure.2 Representative results obtained with 14 RAPD primers
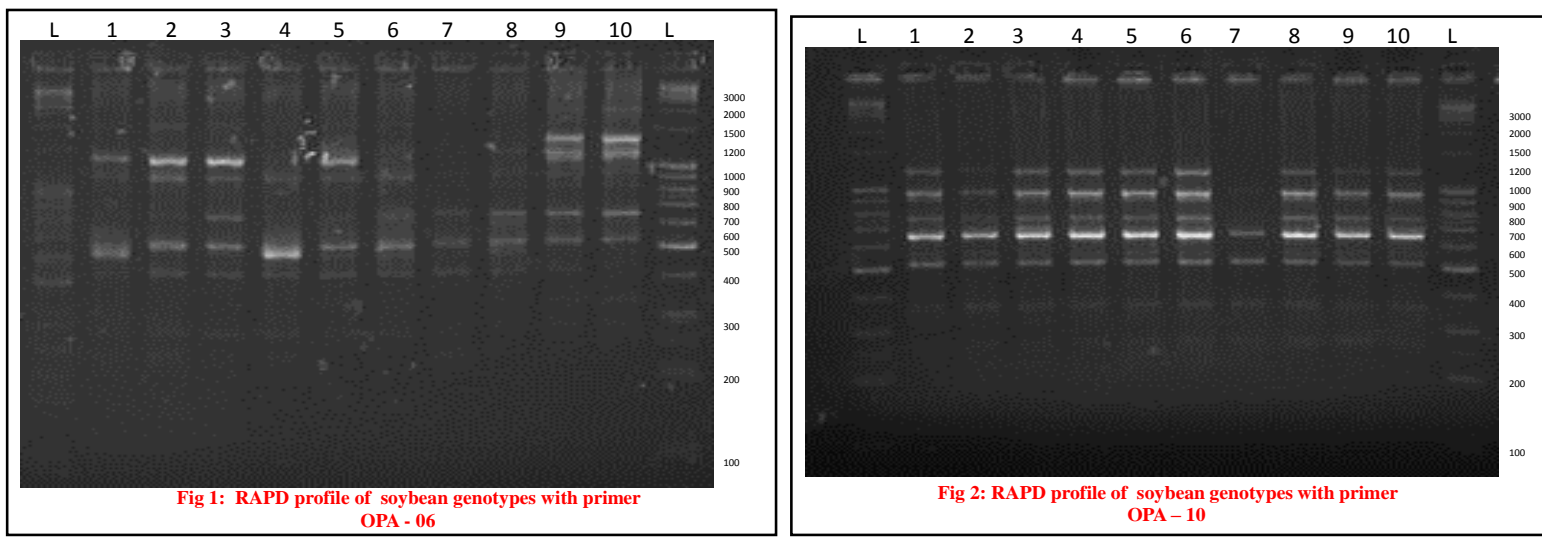

Fig 2: RAPD profile of soybean genotypes with primer OPA -10
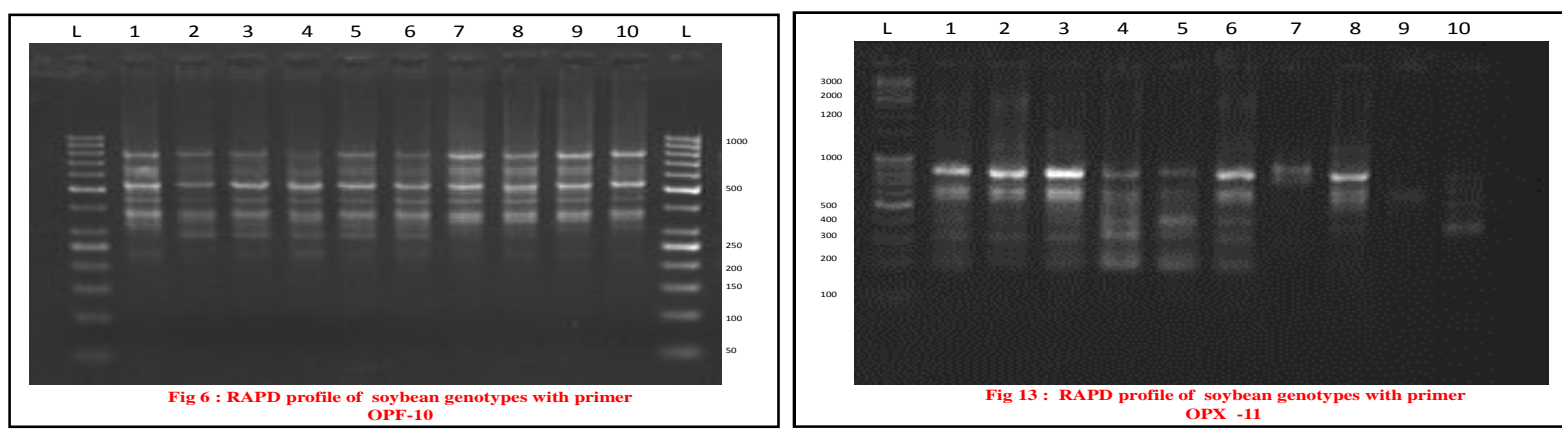

\begin{tabular}{|c|c|c|c|}
\hline Sr. No & Variety & Sr. No & Variety \\
\hline L & 1 kb DNA Ladder & Lane 6 & MAUS-61-2 \\
\hline Lane 1 & MAUS-1 & Lane 7 & MAUS-71 \\
\hline Lane 2 & MAUS-2 & Lane 8 & MAUS-81 \\
\hline Lane 3 & MAUS-32 & Lane 9 & MAUS-158 \\
\hline Lane 4 & MAUS-47 & Lane 10 & \\
\hline Lane 5 & MAUS-61 & & \\
\hline
\end{tabular}

Although there was low variation shown by previous studies; present study shows high variation in comparison, because polymorphism ratio is mainly affected by sequences of primers, types and number of lines being evaluated (Keim et al., 1997). Thus, clusters analysis can help to confirm characters like maturity duration, flower colour, seed shape, oil content, pest and disease resistant and non-shattering habit as distinct characters. It clearly indicates that geographical origin and phenotypic characters play important role in cluster formation and genetic relationships (Zenglu et al., 2001). Our results supported previous studied results wherein a very high level of genetic variability had been reported. These results showed $67.6 \%$ genetic diversity in soybean (Glycine max L.) and wild soybean (Glycine soja) indicating inter varietal relationship of soybean have a narrow genetic base and between varieties are more closely related, while wild soybean is quite distantly related (Lee et al., 1998).

\section{References}

Abdelnoor, Ricordo, V., Everaldo, G., de B., and Maurilio, A.M. 1995. Determination of genetic diversity within Brazilian soybean germplasm using random amplified polymorphic 
DNA techniques and comparative analysis with pedigree data. Rev., Brazil Genet., 18(2): 265-273.

Anonymous. 2009. http// www.usda.org.in. Anonymous. 2006. Annual report of AICRP on Soybean 2008-09, submitted to M.K.V., Parbhani.

Bhat, K.V., P.P. Babrekar and S. Lakhanpant. 1999. Study of genetic diversity in Indian and exotic sesamum (Sesamum Indicum) (L.) germplasm using RAPD markers. Euphytica, 110: 21-23.

Karp, A. Kresovich, S. Bhat, K.V., Ayad, W.G. and Hodgkin, T. 1997. Molecular tools in plant genetic resources conservation: A guide to the technologies, IPGRI, Rome, Italy.

Keim, P. Schupp, J.M. Travis, S.E. Clayten, K. Zhu T. Shi L. Ferreviva A.R. and Webb, D.M. 1997. A high density soybean genetic map based on AFLP markers. Crop Sci., 37: 537-543.

Lee S.K. and Kim B.J. 1998. Analysis of genetic diversity in soybean varieties using RAPD markers. J. Korean Soc. Grassland Sci., 18(4): 227-284.

Rohlf, F.J. NTSYS-PC, 1993. Numerical Taxonomy and multivariate analysis system. Ver., 1.60. Exeter Publ. Ltd., Setauket, New York.

Saghai, M.M.A., K.M. Saliman, R.A. Jorgenson and A.W. Allord. 1984. Ribosonal specer legth polymorphism in barely: Mandelian inheritance, chromosomal location and population dynamics. Proc. Wathl. Acad. Sci., (USA), 81: 8014-8018.

Zenglu, Li. Liuan Qiu, A., Jeffery, Thompson. Mollm Welsh and Randall L., Nelson. 2001. Molecular genetic analysis of US and Chinese soybean ancestral lines. Crop Sci., 41: 1330-1336.

\section{How to cite this article:}

Bharose, A.A., V.D. Kulkarni and Damse, D.N. 2017. Molecular Diversity Analysis of Soybean Genotypes Using Molecular Markers. Int.J.Curr.Microbiol.App.Sci. 6(3): 1723-1729. doi: https://doi.org/10.20546/ijcmas.2017.603.198 